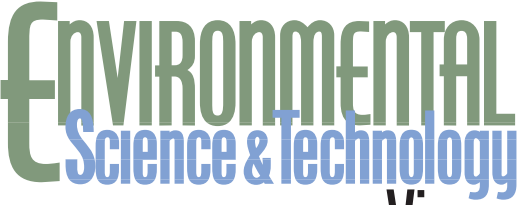 \\ Vieupoint
}

\section{The New World of the Anthropocene ${ }^{1}$}

\author{
J A N Z A L A S I E W I C Z* \\ Department of Geology, University of Leicester, U.K.
}

MARK W I L L I A M S

Department of Geology, University of Leicester, U.K. and British Geological Survey, Nottingham, U.K.

\section{W ILL STEFFEN}

Australian National University, Canberra

PA U L CR U T ZEN

Max-Planck-Institute for Chemistry, Mainz, Germany

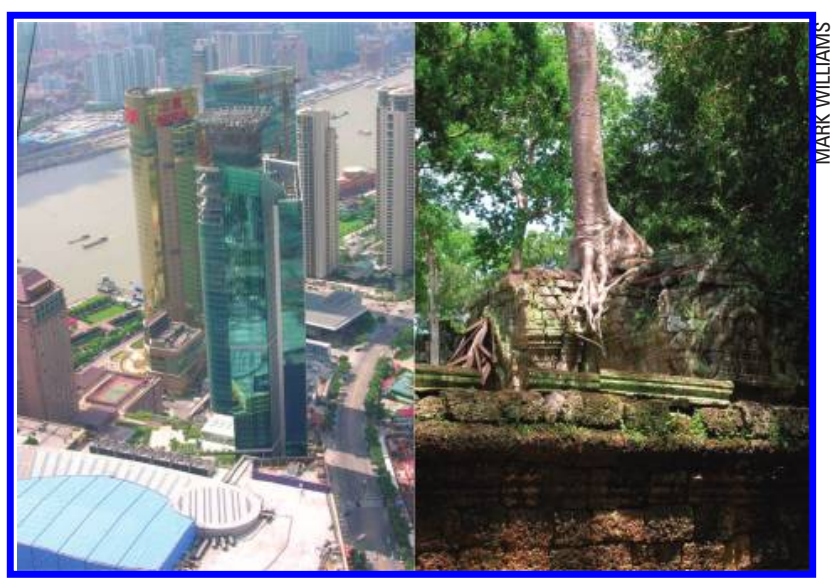

Left - Skyscrapers on the east bank of the Huangpu River in Shanghai, China, photographed from the viewing platform of the Oriental Pearl Tower. Shanghai now has a population approaching 20 million inhabitants. Right - Ta Prohm, Angkor, Cambodia. Stones of this Buddhist monastery built in the late 12th century are held in a grip by Kapok trees. Angkor may have been the world's first 'million city' long before London.

The Anthropocene, following the lost world of the Holocene, holds challenges for both science and society.

The notion that humankind has changed the world is not new. Over a century ago, terms such as the Anthropozoic (1), Psychozoic (2), and Noosphere (3) were conceived to denote the idea of humans as a new global forcing agent.

${ }^{1}$ Editor's Note: This manuscript was submitted prior to ES\&T changing its manuscript parameters for Viewpoints. For the new format, please read the details at http://pubs.acs.org/doi/abs/10.1021/ es903081n.
These ideas received short shrift in the geological community (4), seeming absurd when set aside the vastness (newly realized, also) of geological time. Moreover, the scarring of the landscape associated with industrialization may appear as transformation, but the vicissitudes of the geological past-meteorite strikes, extraordinary volcanic outbursts, colliding continents, and disappearing oceansseemed of an epic scale beyond the largest factories and most populous cities.

So when one of us (P.C.) proposed the new term "Anthropocene" for this concept a decade ago (5), why did it not also become a discarded footnote in the history of geological ideas? It helps that the term is vivid, as much for the public as for scientists. More importantly, it was coined at a time of dawning realization that human activity was indeed changing the Earth on a scale comparable with some of the major events of the ancient past. Some of these changes are now seen as permanent, even on a geological time-scale.

Hence, the term Anthropocene quickly began to be used by practicing scientists (6) to denote the current interval of time, one dominated by human activity. The term, though, was (and currently remains) informal and not precisely defined. However, in 2008, the Stratigraphy Commission of the Geological Society of London decided, by a large majority, that there was merit in considering the possible formalization of this term: that is, that it might eventually join the Cambrian, Jurassic, Pleistocene, and other such units on the Geological Time Scale (7).

Note the careful wording. This was not the same as formalizing the term (this Commission does not have that power). Nevertheless, it was a clear signal that a body of independent geologists (each chosen for their technical expertise in the discipline of stratigraphy) thought that the case should be examined further.

The first (of many) formal steps are now being taken. An Anthropocene Working Group has been initiated, as part of the Subcommission on Quaternary Stratigraphy (the body that deals with formal units of the current Ice Ages). That is itself part of the International Commission on Stratigraphy, in turn answerable to the International Union of Geological Sciences. All of these bodies will have to be convinced that the case to formally include the Anthropocene in the Geological Time Scale is overwhelming, and, if so, to agree on a formulation of it that will be widely acceptable. The work involved will take several years to accomplish, and the outcome is not certain. The Geological Time Scale is held dear by geologists (because it is fundamental to their work), and it is not amended lightly.

In this article, therefore, we outline the scale of human modification of the Earth on which the concept of the Anthropocene rests, describe the means by which geological time units are established, and discuss the particular problems and implications of discussing the Anthropocene as a formal geological time term.

\section{The Scale of Environmental Change}

First, how have the actions of humans altered the course of Earth's deep history? The answers boil down to the unprec- 
edented rise in human numbers since the early nineteenth century-from under a billion then to over six billion now, set to be nine billion or more by midcentury. This population growth is intimately linked with massive expansion in the use of fossil fuels, which powered the Industrial Revolution, and allowed the mechanization of agriculture that enabled those additional billions to be fed.

The most plainly visible physical effects of this on the landscape-the growth of the world's megacities, for instance-may in some ways be the most transient. In such "terraforming", humans have brought about a roughly orderof-magnitude increase in the long-term rate of erosion and sedimentation $(8,9)$. This is a remarkable, though perhaps short-lived, sedimentary signal. If construction stops or slows, for whatever reason, then natural geomorphologic processes will rapidly re-establish themselves, as shown by the fate of "lost" cities such as Angkor in Cambodia.

Far more profound are the chemical and biological effects of global human activity. It may seem remarkable that changes to mere trace components of the Earth's atmosphere- $\mathrm{CO}_{2}$, methane $\left(\mathrm{CH}_{4}\right)$, and so on-can so fundamentally impact the Earth. Nevertheless, the concept of control of surface temperature by levels of greenhouse gases (GHGs), as originally worked out by Arrhenius (10) and Chamberlain (11), has been vindicated by subsequent work. Today, the rise in $\mathrm{CO}_{2}$ to over a third above preindustrial levels has been demonstrated beyond reasonable doubt: by systematic measurement since the 1950s (12); and by the record of atmospheric composition, now nearly a million years long, preserved in Antarctic ice (13).

The rise in temperatures, that, at high latitudes, already exceed modeled predictions, has important consequences. The fringes of the great polar ice-sheets, once thought to react sluggishly to temperature rises, are now seen to respond quickly and dynamically (14). The ensuing sea level rise, scarcely begun, may ultimately be of the order of several meters (15) if temperatures rise by some $2-5^{\circ} \mathrm{C}$, as predicted (16).

Global temperature rises will have far-reaching consequences for the biosphere. Species will migrate (if they are able to) to track their optimum climate belt, a phenomenon more pronounced in the oceans than on land (17): changes in, say, larval hatching times can cause cascade-like changes in entire ecosystems, when these larvae act as food for other animals.

The ultimate effect on the biosphere of climate change coupled with other human stressors (habitat fragmentation, invasive species, predation) is a sharp increase in the rate of extinctions (18). Current estimates put the extinction rate at 100-1000 times greater than the background level $(18,19)$, and the rate is projected to increase by a further 10 -fold this century (18). This current human-driven wave of extinctions looks set to become Earth's sixth great extinction event (20).

Enhanced dissolution of increased atmospheric $\mathrm{CO}_{2}$ in the oceans, too, is increasing their acidity. Significant drops in oceanic $\mathrm{pH}$ have already occurred, and further projected decreases will stress calcifying organisms such as reef corals, though the biological response is complex (21). This factor alone may substantially change marine ecosystems over the next century.

\section{The Stratal Context}

The above summarizes some of the environmental changes currently taking place. The Anthropocene, though, if it is to be used as a formal geological term, needs to be placed within a context of Earth history. We need to know, therefore, how that history is analyzed and classified.

In the Geological Time Scale (22), the fundamental units of the Earth's 4.57 billion year history are named, defined, and arranged. Names such as "Jurassic" are used partly because they are useful and convenient (much as historians use terms such as "Roman" and "Victorian") and partly because the framework of the Earth's history was essentially worked out before radiometric dating was discovered: the early geologists had essentially no idea of how old the Earth really was.

Those early geologists, though, could recognize that particular stratal successions contained distinctive fossils-for example the strata of the Jura Mountains with particular fossil mollusks. Such fossil assemblages could be traced around the world to establish a stratal unit that was translated into a time unit: the Jurassic. It was only much later that the Jurassic Period was found to start about 200 million years ago and finish some 145 million years ago. But, for many practical purposes, this did not matter-one could still classify and correlate rocks and build up a coherent Earth history.

The precise definition of these units has been (and remains) troublesome. Even after the advent of radiometric dating, they were mostly not defined in terms of agreed ages - for instance by saying that the Jurassic Period started at 200 million years ago exactly. This is because, even now, radiometric dating remains too imprecise to allow the boundary to be fixed precisely: there would be about a half a million year's "fuzziness" around it.

Today, one typically looks for a "marker" level where the strata above and below are recognizably different (usually because they contain different types of fossils) and then selects the place in the world that best shows that level. That point then is chosen to represent, formally, the beginning of a geological time unit. Its title is grand-it is a Global Stratigraphic Section and Point, but more popularly it is known as a "golden spike"; it is the standard reference level for a geological time boundary.

Many such formal time boundaries mark upheavals in Earth history. This is mostly for practical reasons. It is easy to tell Tertiary strata from Cretaceous strata because the former lack fossils of the many types of organisms (ammonites, dinosaurs, and so on) that died out in the abrupt end-Cretaceous mass extinction event. Therefore, the extinction event itself is the obvious marker, signaling the transition from one Earth dynasty to another.

However, although the names of the main geological periods and eras are familiar to any first-year geology student, defining them precisely has been procedurally prolonged and often controversial. Not all geological time boundaries are as clear-cut as that at the end of the Cretaceous Period: transition between successive dynasties of Earth history were often complex and protracted, and in such cases an optimal level has to be decided upon to represent a formal boundary, typically after extensive academic debate. There are tussles too (often with a hint of nationalism) over which stratal section in which country should have the honor of hosting the golden spike. The Ordovician Period, for instance, took over 20 years to define. Only this year, the Quaternary Period (that we live in) has been formally modified to more exactly correspond to the beginning of full glaciation on Earth, after a process that can best be described as fraught (23). It is unlikely that the Anthropocene will have an easy and uncontested passage through the various committeesparticularly as it is novel not just as a time unit, but novel, indeed unprecedented, as regards its analysis and consideration.

\section{Assessing the Anthropocene}

All of the previous geological eras, periods, and epochs have been defined in geological terms, by comparing one set of rock strata with another. Earth scientists have grown increasingly sophisticated in interpreting strata in terms of 
the history they represent. Nevertheless, the Earth's history has been only patchily preserved, with substantial biases.

The Anthropocene is different. We are (formally or informally) living within it, and are able to observe landscape, assess living biodiversity, measure atmospheric composition and sea temperature, gauge ice thickness and sea level height. Thus, considerable translation is needed to describe this unit of one discipline with the languages and measures of other disciplines. The Anthropocene Working Group hence, uniquely, needs to include botanists, zoologists, atmospheric, and ocean (and other) scientists as well as geologists.

The Anthropocene is represented physically by the sediment layers that have accumulated in recent years. Some of these layers are human-made-the concrete and bricks of our roads and cities. Others are heavily modified-the soils of our fields, and the polluted muds of estuaries. Yet others have formed bereft of measurable human influence-the recent sand dunes of the Sahara or the Empty Quarter of Arabia. All are Anthropocene (because this is a unit of time, and not of process), and their distinctiveness and the ease of their separation from older (pre-Anthropocene) strata will be crucial to decisions about formalizing this unit.

Cross-comparing the data from present and past will not be easy. Take the biological signal. In ancient strata, this is represented almost exclusively by fossils. Not all organisms fossilize equally well: most do not have tough skeletons or hard shells, and so scarcely fossilize at all. Marine organisms are more likely to be fossilized than terrestrial ones (because the land is largely a realm of erosion and the sea is one of sediment accumulation). And fossils of terrestrial organisms almost all come from low-lying coasts and river plains; our knowledge of mountain-dwelling organisms of the geological past is virtually nil.

By contrast, modern assessment of living organisms, of their survival or extinction, is done without reference to how tough their skeleton is. We know more of what is going on on land (where we live) than in the sea. And we have a better assessment of "popular" organisms (such as butterflies and mammals), that rarely fossilize, than of the humble invertebrates that are better potential fossils. This is not to say that comparison of the living world and the ancient one is impossible. But care will be needed to say how significant is the current, ongoing extinction event by comparison with those that have refashioned life in the past-and therefore how significant is the Anthropocene, biologically.

There is another major difference between the Anthropocene and the previous geological ages. These others have all terminated: we know their entire history. The Anthropocene is ongoing. By almost any measure, the effects of the human perturbation will continue for centuries and millennia; some (such as the biotic change wrought) will have permanent effects. The long-term extent of this "built-in" future change is currently unknowable, as it largely depends on the interplay of feedback effects that will either amplify or diminish the effects of anthropogenic change.

The Anthropocene is, so far, geologically very brief-in the original concept (from the beginning of the Industrial Revolution) merely a couple of centuries. This need not detract from its value as a geological time unit, because the Geological Time Scale is utilitarian, not abstract. Most epochs, for instance, are typically several million years in duration. However, we are currently (formally, still) living in the Holocene Epoch, which started just over 11,000 years ago. The Holocene is merely the last of some one hundred climate phases of the Quaternary Period. This is not symmetrical, but it makes practical sense to humans, as we are surrounded by and live on Holocene sedimentary deposits and have to deal with them-for engineering, agriculture, and so on-every day.

Similarly, Anthropocene strata form part of our surrounding environment (we live in and drive on Anthropocene rock constructions that we call houses and roads, for example). Furthermore, the Holocene is essentially a standard interglacial phase, albeit perhaps prolonged by modest preindustrial greenhouse gas emissions associated with early agriculture (24). The Anthropocene, by contrast, is geologically unique and in many ways novel: no previous migrations of organisms, for instance, have rivalled the human-caused introductions of alien species $(20,25)$.

\section{Scale and Beginning of the Anthropocene}

In common language, epochs and eras are largely interchangeable. Not so in geology. An era is a very large-scale unit-the Mesozoic, the entire near-two-hundred-millionyear time span of the dinosaurs, is made up of the Triassic, Jurassic, and Cretaceous periods, for instance. Epochs are much more modest, being subdivisions of geological periods. As well as duration, what is important is distinctiveness - and that reflects the scale of environmental change across the boundaries. The Mesozoic is bracketed by the two largest and most abrupt mass extinctions known (the PermianTriassic, or P-T, boundary when over $90 \%$ of species were killed off, and the Cretaceous-Tertiary, or K-T, when the dinosaurs - and much else-disappeared), while epoch boundaries represent smaller-scale changes.

What might the Anthropocene be, on current evidence? Consideration of it as an epoch seems reasonable, and conservative. The scale of change taken place so far, or that is imminent or unavoidable, appear to have already taken the Earth out of the envelope of conditions and properties that mark the Holocene Epoch. There are geological precedents: the start of the Eocene Epoch, 55 million years ago, was marked by (natural) greenhouse gas releases, comparable in scale (if slower than) anthropogenic $\mathrm{CO}_{2}$ releases (26), associated with ocean acidification and extinction events.

When should a formal Anthropocene Epoch begin? Should it be linked with the Industrial Revolution-or with the postwar "Great Acceleration" (27) of global environmental change? The latter is associated with the first human-caused atomic detonations, a factor that is more than just symbolic: the world's strata from 1945 on contain tiny but measurable amounts of artificial radionuclides (28). Should the beginning of the Anthropocene be fixed by a simple date (say, 1800, or perhaps 1945)? Or should one seek to place a "golden spike" as global reference point within some recent strata? Such practical questions will need resolution prior to formalization.

\section{Implications}

Whether to formalize the Anthropocene or not is a question that will be decided on geological, and, more precisely, stratigraphic grounds. Does the present scale of the global change, measured against deep Earth history, justify the term?- and will formalizing the term be beneficial to working scientists?

It can be argued that a formal Anthropocene Epoch would inherently downplay the scale and significance of preindustrial (early agricultural) modification of landscape $(24,29)$ and oversimplify the complex and historically protracted human effects on the natural environment. In response, one might say that existing formal boundaries within deep geological time do not typically have such a deleterious scientific effect; more typically the research carried out to establish them illuminates the complex course of palaeoenvironmental history. Regardless, the Anthropocene has taken root in the scientific community, and is now unlikely to decline through practical neglect by working scientists.

The term, also, has a resonance that goes beyond the modification of a geological classificatory scheme. It has attracted public interest, probably because it encapsulatesindeed integrates - the many and diverse kinds of environ- 
mental change that have taken place. The transition from the Holocene into the Anthropocene may be developed, too-somewhat controversially-into the concept of planetary boundaries (30), wherein a safe operating space for humanity may be defined. Moreover, formalization may represent "official" acknowledgment that the world has changed, substantially and irreversibly, through human activity-an acknowledgment akin to the IPCC consensus statements on climate change.

Much of this global change will be to the detriment of humans. Not all of it (Greenland, for example, is currently greening-and booming), but the present and likely future course of environmental change seems set to create substantially more losers, globally, than winners.

The concept of the Anthropocene might, therefore, become exploited, to a variety of ends. Some of these may be beneficial, some less so. The Anthropocene might be used as encouragement to slow carbon emissions and biodiversity loss, for instance; perhaps as evidence in legislation on conservation measures (31); or, in the assessment of compensation claims for environmental damage. It has the capacity to become the most politicized unit, by far, of the Geological Time Scale-and therefore to take formal geological classification into uncharted waters.

However these debates will unfold, the Anthropocene represents a new phase in the history of both humankind and of the Earth, when natural forces and human forces became intertwined, so that the fate of one determines the fate of the other. Geologically, this is a remarkable episode in the history of this planet.

Jan Zalasiewicz and Mark Williams are members of the Stratigraphy Commission of the Geological Society of London; Jan is also ViceChair of the International Subcommission on Stratigraphic Classification, while Mark leads the palaeoclimate team of the British Geological Survey. Will Steffen served as Director of the International Geosphere-Biosphere Programme, and is now Director of the ANU Climate Change Institute. Paul Crutzen, awarded a Nobel Prize in Chemistry in 1995 for his work on atmospheric ozone, is Professor emeritus at the Max-Planck-Institute for Chemistry, Mainz. Correspondence regarding this article should be addressed to jaz1@le.ac.uk

\section{Literature Cited}

(1) Stoppani, A. Corsa di Geologia; Milan, 1873.

(2) Le Conte, J. Elements of Geology; D. Appleton \& Co: New York, 1879.

(3) Le Roy E. L'exigence idéaliste et le fait de l'évolution (Idealistic Exigency and the feat of Evolution); Boivin: Paris, 1927.

(4) Berry, E. W. The term Psychozoic. Science 1925, 44, 16.

(5) Crutzen, P. J. Geology of Mankind. Nature 2002, 415, 23.

(6) Syvitski, J. P. M.; Vörösmarty, C. J.; Kettner, A. J.; Green, P. Impact of humans on the flux of terrestrial sediment to the global coastal ocean. Science 2005, 308, 376-380.

(7) Zalasiewicz, J.; Williams, M.; Smith, A.; Barry, T. L.; Bown, P. R.; Rawson, P.; Brenchley, P.; Cantrill, D.; Coe, A. E.; Gale, A.; Gibbard, P. L.; Gregory, F. J.; Hounslow, M.; Kerr, A.; Pearson, P.; Knox, R.; Powell, P.; Waters, C.; Marshall, J.; Oates, M.; Rawson, P.; Stone, P. Are we now living in the Anthropocene? GSA Today 2008, 18 (2), 4-8.

(8) Hooke, R. LeB. On the history of humans as geomorphic agents. Geology 2000, 28, 843-846.

(9) Wilkinson, B. H. Humans as geologic agents: A deep-time perspective. Geology 2005, 33, 161-164.

(10) Arrhenius, S. On the influence of carbonic acid in the air upon the temperature of the ground. London, Edin., and Dublin Phil. Mag. and J. Sci. (fifth series) 1896, 41, 237-275.

(11) Chamberlin, T. C. A Group of Hypotheses Bearing on Climatic Changes. I. Geol. 1897, 5, 653-83.
(12) Keeling, R. F.; Piper, S. C.; Bollenbacher, A. F.; Walker, J. S. Atmospheric $\mathrm{CO}_{2}$ records from sites in the SIO air sampling network. In Trends: A Compendium of Data on Global Change; Carbon Dioxide Information Analysis Center, Oak Ridge National Laboratory, U.S. Department of Energy: Oak Ridge, TN, 2009; doi: 10.3334/CDIAC/atg.035; available at http://cdiac.ornl.gov/ trends/co2/sio-mlo.html.

(13) EPICA Community Members 2004. Eight glacial cycles from an Antarctic ice core. Nature 2004, 429, 623-628.

(14) Overpeck, J. T.; Otto-Bliesner, B. L.; Miller, G. H.; Muhs, D. R.; Alley, R. B.; Kiehl, J. T. Paleoclimatic evidence for future icesheet instability and rapid sea-level rise. Science 2006, 311, 17471750.

(15) Rahmstorf, S. A semi-empirical approach to projecting future sea-level rise. Science 2007, 315, 368-370.

(16) Intergovernmental Panel on Climate Change. Climate change 2007: synthesis report. Summary for policy makers; IPCC, 2007; available at http://www.ipcc.ch/SPM2feb07.pdf.

(17) Edwards, M. Sea life (pelagic and planktonic systems) as an indicator of climate and global change. In Climate Change: Observed Impacts on Planet Earth; Letcher, T. M., Ed.; Elsevier: Amsterdam, 2009.

(18) Mace, G.; Masundire, H.; Baillie, J. \& colleagues. Biodiversity. In Ecosystems and Human Wellbeing: Current State and Trends; Hassan, H., Scholes, R. Ash, N., Eds.; Island Press: Washington DC, 2005.

(19) Pimm, S. L.; Russell, G. J.; Gittleman, J. L.; Brooks, T. M. The future of biodiversity. Science 1995, 269, 347-350.

(20) Chapin, F. S., III; Zaveleta, E. S.; Eviner, V. T.; Naylor, R. L.; Vitousek, P. M.; Lavorel, S.; Reynolds, H. L.; Hooper, D. U.; Sala, O. E.; Hobbie, S. E.; Mack, M. C.; Diaz, S. Consequences of changing biotic diversity. Nature 2000, 405, 234-242.

(21) Kleypas, J. A.; Feely, R. A.; Fabry, V. J.; Langdon, C.; Sabine, C. L.; Robbins, L. L. Impacts of Ocean Acidification on Coral Reefs and Other Marine Calcifiers: A Guide for Future Research; report of a workshop held April 18-20, 2005, St. Petersburg, FL, sponsored by NSF, NOAA, and the U.S. Geological Survey, 2006.

(22) http://www.stratigraphy.org/upload/ISChart2009.pdf.

(23) Gibbard, P. L.; Head, M. J.; Walker, M. J. C. Subcommission on Quaternary Stratigraphy. Formal ratification of the Quaternary System/Period and the Pleistocene Series/Epoch with a base at 2.58 Ma. L. Quat. Sci. 2009; DOI: 10.1002/jqs.1338.

(24) Ruddiman, W. F. The anthropogenic Greenhouse Era began thousands of years ago. Climate Change 2003, 61, 261-293.

(25) Vitousek, P. M.; Mooney, H. A.; Lubchenco, J.; Melillo, J. M. Human domination of Earth's ecosystems. Science 1997, 277, 494-499.

(26) Cohen, A. S.; Coe, A. L.; Kemp, D. B. The Late Palaeocene-Early Eocene and Toarcian (Early Jurassic) carbon isotope excursions: a comparison of their time scales, associated environmental changes, causes and consequences. J. Geol Soc. Lond. 2007, 164, 1093-1108.

(27) Steffen, W.; Crutzen, P. J.; McNeill, J. R. The Anthropocene: Are humans now overwhelming the great forces of Nature? Ambio 2007, 36, 614-621.

(28) Marshall, W. A.; Gehrels, W. R.; Garnett, M. H.; Freeman, S. P. H. T.; Maden, C.; Xu, S. The use of 'bomb spike' calibration and high-precision AMS 14C analyses to date salt marsh sediments deposited during the last three centuries. Quat. Res. 2007, 68, 325-337.

(29) Kaplan, J. O.; Krumhardt, K. M.; Zimmermann, N. The prehistoric and preindustrial deforestation of Europe. Quat. Sci. Rev. 2009; doi:10.1016/j.quascirev.2009.09.028.

(30) Rockström, J.; Steffen, W.; Noone, K.; Persson, Å.; Chapin, F. S., III; Lambin, E. F.; Lenton, T. M.; Scheffer, M.; Folke, C.; Schellnhuber, H. J.; Nykvist, B.; de Wit, C. A.; Hughes, T.; van der Leeuw, S.; Rodhe, H.; Sörlin, S.; Snyder, P. K.; Costanza, R.; Svedin, U.; Falkenmark, M.; Karlberg, L.; Corell, R. W.; Fabry, V. J.; Hansen, J.; Walker, B.; Liverman, D.; Richardson, K.; Crutzen, P.; Foley, J. A. A safe operating space for humanity. Nature 2009, 461, 472-475.

(31) Vidas, D. Responsibility for the Seas. In Law, Technology and Science for Oceans in Globalisation; Vidas, D., Ed.; Martinus Nijhoff Publishers/Brill: The Hague, 2010.

ES903118J 